\title{
Assessment of Physicochemical and Microbiological Quality of Jersey Cattle Raw Milk at Different Stages of Lactation
}

\author{
G. O. Tona ${ }^{1}$, I. C. Oladipo ${ }^{2}$, S. O. Oseni ${ }^{3}$ \\ ${ }^{1}$ Department of Animal Production and Health, Ladoke Akintola University of Technology, Ogbomoso, Oyo State, Nigeria \\ ${ }^{2}$ Department of Science Laboratory Technology, Ladoke Akintola University of Technology, Ogbomoso, Oyo State, Nigeria \\ ${ }^{3}$ Department of Animal Sciences, Obafemi Awolowo University, Ile-Ife, Osun State, Nigeria
}

\begin{abstract}
The physico-chemical and micro-biological properties of raw milk from Jersey breed cows at different stages of lactation were investigated. Raw milk samples were collected from twelve Jersey cows at the colostrum, early lactation, mid lactation and late lactation stages, at a commercial feedlot dairy farm located in Edu Local Government Area, Kwara State, Nigeria. The results showed that the Jersey cows raw milk were characterised by high physicochemical qualities. The pH ranged between 5.93 and 7.00. The ranges of specific gravity (1.11), titrable acidity (0.18 to $0.23 \%$ lactic acid), ether extract (4.83 to 6.07\%) and viscosity (175.23 to 243.50 centistrokes) were observed. The Jersey cows raw milk samples were also of good microbiological qualities. Total viable bacteria counts ranged from $1.9 \times 10^{3} \mathrm{cfu} / \mathrm{ml}$ in the late lactation milk, $2.3 \times 10^{2} \mathrm{cfu} / \mathrm{ml}$ in the colostrum, $5.0 \times 10^{2} \mathrm{cfu} / \mathrm{ml}$ in the early lactation milk and $8.6 \times 10^{2} \mathrm{cfu} / \mathrm{ml}$ in the mid lactation milk. The Bacillus species and Pseudomonas species bacteria were identified. The total viable bacteria counts observed in this study are within the $2.0 \times 10^{5} \mathrm{cfu} / \mathrm{ml}$ bacterial count of the ISI (International Standards Index) limits for raw milk. There was no coliform organism observed in the colostrum, early lactation and mid lactation milk. Aeromonas species organism with a total coliform count of $2.3 \times 10^{2} \mathrm{cfu} / \mathrm{ml}$ was observed in the late lactation milk. The value of total coliform counts observed in the current study met required standard. Rhizopus species and Aspergillus species fungi with total fungal counts of between $1.3 \times 10^{2} \mathrm{cfu} / \mathrm{ml}$ (colostrum), $2.5 \times 10^{3} \mathrm{cfu} / \mathrm{ml}$ (early lactation), $3.2 \times 10^{3} \mathrm{cfu} / \mathrm{ml}$ (late lactation) and $3.3 \times 10^{3} \mathrm{cfu} / \mathrm{ml}$ (mid lactation) milk were observed. It can be concluded that the raw Jersey cattle milk samples (collected from the commercial dairy farm in Edu Local Government Area, Kwara state, Nigeria) at the different stages of lactation were of good physicochemical and microbiological qualities and this may be due to maintaining better hygiene conditions.
\end{abstract}

Keywords: Jersey cows, raw milk, physicochemical parameters, microbiological quality

\section{Introduction}

Nigeria is richly endowed with a wide variety of animal protein resources such as meat, milk, eggs and fish, however, the total production is insufficient to meet the requirement of the populace. The prevailing need to bridge the gap between recommended animal protein intake and actual consumption in Nigeria informs the renewed effort channelled towards the importation of exotic dairy cattle, such as the Jersey breed cattle into the country [1]. The rearing of improved exotic breeds would potentially serve selected niches in the Nigeria milk supply. Milk is an important source of all the basic nutrients required by mammals including human beings and it serves as a complete food for feeding young mammals. Milk production in lactating ruminants can be divided into the colostrum, early lactation, mid lactation and late lactation stages. The physicochemical properties of milk include the physical state, acidity, $\mathrm{pH}$, specific gravity, boiling point, freezing point, refractive index, viscosity, colour, flavour and nutritive value [2]. Milk being highly nutritious serves as a good medium for the growth of micro-organisms such as bacteria and fungi. However, low microbial count in milk is necessary to avoid or minimize the deleterious effects caused by disease causing microbes that may be present in milk. The major chemical components of milk include water, fats, proteins, carbohydrates, minerals, organic acids, enzymes and vitamins [3]. However, it is highly perishable when kept at room temperature and there would be rapid setting up and multiplication of various micro - organisms particularly, bacteria. The quality of raw milk is described on the basis of several attributes which include milk characteristics such as chemical composition, physical properties, microbiological and cytological quality, sensory properties, technological suitability and nutritive value [4]. It is very difficult to assure high quality and desirable physicochemical properties of raw milk designed for processing, since this is dependent on several factors which also include genetic factors such as breed [5]. Again, it was reported that some differences in the chemical composition and physicochemical properties of milk from different dairy cattle breeds are determined genetically [1], [5]. Some researchers [5] also mentioned that selection in terms of milk composition is directed towards increasing protein concentration and the protein: fat ratio. Jersey cows have been reported to out class other exotic cows in terms of milk fat and lactose contents [1] and also in terms of milk calcium content, milk casein content and milk with bigger fat globules [5]. The quality evaluation of raw milk is usually carried out based on various tests including organoleptic test, appearance, physicochemical and bacteriological qualities. The aim of this research was to evaluate the physicochemical parameters and the micro-biological qualities of the Jersey cow raw milk samples at different (colostrum, early lactation, mid lactation and late lactation) stages of lactation.

\section{Volume 5 Issue 6, June 2016 www.ijsr.net}




\section{International Journal of Science and Research (IJSR)}

ISSN (Online): 2319-7064

Index Copernicus Value (2013): 6.14 | Impact Factor (2015): 6.391

\section{Materials and Methods}

\section{Study area and ethical issue}

The raw milk samples used for the study were collected from a commercial dairy farm in Edu Local Government Area, Kwara state, Nigeria. Prior to the commencement of the study, a letter of permission was obtained from the General Manager at the Farm Office in Ilorin, Kwara State capital town, Nigeria.

\section{Collection of raw milk samples}

Raw milk samples were collected from twelve lactating Jersey cows that were machine milked in the morning at $8.00 \mathrm{~h}$. The cows were all at the first parity (primiparous). The experiment was carried out between the period of $1^{\text {st }}$ February to $30^{\text {th }}$ November, 2015. A total of 12 raw milk samples were collected for analysis at each stage of lactation. The four stages of lactation were as follows; at the colostrum ( $2^{\text {nd }}$ day in lactation), early lactation $\left(56^{\text {th }}\right.$ day in lactation $)$, mid lactation $\left(150^{\text {th }}\right.$ day in lactation) and late lactation $\left(270^{\text {th }}\right.$ day in lactation) stages. Thus in all, 48 raw milk samples were collected for laboratory analysis. About $50 \mathrm{ml}$ of Jersey cow raw milk samples were collected into sterile bottles in a cooler of ice-pack and transported immediately to the laboratory. The laboratory analysis were carried out at the Animal Production and Health and the Science Laboratory and Technology Departmental laboratories of Ladoke Akintola University of Technology (LAUTECH), Ogbomoso, Nigeria.

\section{Laboratory analysis for physicochemical properties of milk samples}

The raw milk samples (20 mls each) were analysed in triplicates for their $\mathrm{pH}$, specific gravity, titrable acidity, ether extract and viscosity characteristics.

The $\mathrm{pH}$ measurements were made using a digital $\mathrm{pH}$ meter, which was initially standardized with standard buffer solution of $\mathrm{pH} 4$ and 7. The $\mathrm{pH}$ electrode was washed with distilled water and placed in each milk sample, then a few seconds was allowed for the reading to stabilize and the $\mathrm{pH}$ value was recorded.

The titrable acidity was measured by titrimetric method. Each of the milk samples used for the $\mathrm{pH}$ determination was transferred into a $250 \mathrm{ml}$ conical flask, then 4 to 5 drops of phenolphthalein indicator was added. Then a $25 \mathrm{ml}$ burette was filled with $0.1 \mathrm{M}$ sodium hydroxide and titrated with the $0.1 \mathrm{M}$ sodium hydroxide until the indicator just turned pink. The titre volume of sodium hydroxide added was then recorded. The percentage of total titrable acidity was expressed as percent of lactic acid. This was obtained by multiplying the titre volume of sodium hydroxide by 0.09 .

Percent ether extract was determined using the soxhlet apparatus equipment [6].

Other parameters such as the specific gravity and viscosity were also observed [6]. Specific gravity was measured using a lacto-densitometer. Viscosity was measured using a viscometer using a glass tube and a normalized ball equipped with a chronometer at $20^{\circ} \mathrm{C}$ and expressed in centistrokes.
Laboratory analysis of micro-biological characteristics of raw milk samples

The media used in the laboratory analysis of microbiological properties of raw milk samples in this study included the following: MacConkey Agar for coliform organisms, Pseudomonas Agar for pseudomonas, Potato dextrose Agar for fungi, Nutrient Agar for aerobes, Mannitol salt Agar for staphylococcus and de Mannns Rogosa and Sharpe (MRS) for anaerobes.

\section{Standard plate count}

In the standard plate count, one $\mathrm{ml}$ of the milk sample (and in any dilution level) was dispensed into a sterile Petri dish using a sterile pipette. Then $15-20 \mathrm{ml}$ of sterile nutrient agar was added and the two mixed thoroughly by swirling gently. The dish was then incubated in an incubator at $37^{\circ} \mathrm{C}$ for $24 \mathrm{hrs}$. The number of colonies growing in the agar plate was then counted. (N.B.: This method is suitable for enumerating small number of bacteria, hence is suitable for low count samples. This is usually used for pasteurized milk or good quality raw milk.)

Isolation of micro- organisms from the raw milk samples One ml each of the raw milk samples was measured out and subjected to serial dilutions within the ranges of $10^{-1}$ and $10^{-}$ ${ }^{4}$. One $\mathrm{ml}$ of each sample was then thoroughly mixed with 9 $\mathrm{ml}$ of sterile distilled water to give $10^{-1}$ dilution. Then next, $1 \mathrm{ml}$ of the $10^{-1}$ dilution was also pipetted out and mixed with another $9 \mathrm{ml}$ of sterile distilled water, screw capped to give $10^{-2}$ and repeated to give $10^{-3}$ and $10^{-4}$ dilutions repeatedly. A sterile pipette was used to measure out $1 \mathrm{ml}$ out of the $10^{-3}$ and $10^{-4}$ dilutions. It was pipetted into sterile Petri dishes and molten agar at $45^{\circ} \mathrm{C}$ was poured onto it. It was swirled gently for even distribution of the inoculum in the agar. After solidification, the plates were then inverted and incubated in an incubator at $30^{\circ} \mathrm{C}$.

Plates containing the nutrient agar were allowed to stay over night while that of potato dextrose agar was incubated for 3 days. The bacteria grew on the nutrient agar while fungi grew on the potato dextrose agar.

\section{Total bacteria and fungi count and identification}

This was done by counting the different colonies on the different agar plates after incubation and multiplying with the dilution factor. Identification of the isolates was done after examining the cultural, morphological, biochemical, physiological characteristics, including microscopic and macroscopic examination of the various isolates.

\section{Statistical analysis}

Data collected were subjected to one way analysis of variance (ANOVA) procedure [7]. Significant means were separated using the Duncan's multiple range test of the same software. Mean differences were considered significant at $\mathrm{P}<0.05$.

\section{Results}

The physicochemical properties of Jersey cows raw milk samples at different stages of lactation are shown in Table 1. The values observed were all significantly different $(\mathrm{P}<0.05)$ except for the values of specific gravity of Jersey cows raw 


\section{International Journal of Science and Research (IJSR) \\ ISSN (Online): 2319-7064 \\ Index Copernicus Value (2013): 6.14 | Impact Factor (2015): 6.391}

milk samples that were similar $(\mathrm{P}>0.05)$. Presented in Table 2 are the micro-biological qualities of Jersey cows raw milk samples at different stages of lactation. Table 3 shows the
International Standard Index (ISI) specifications for microorganism counts in raw milk [2].

Table 1: Physicochemical properties of Jersey cows raw milk samples at different stages of lactation

\begin{tabular}{|c|c|c|c|c|}
\hline Parameters & Colostrum & $\begin{array}{c}\text { Early lactation } \\
\text { Milk }\end{array}$ & $\begin{array}{c}\text { Mid lactation } \\
\text { Milk } \\
\end{array}$ & $\begin{array}{c}\text { Late lactation } \\
\text { Milk } \\
\end{array}$ \\
\hline $\mathrm{pH}$ & $6.00 \pm 0.33^{\mathrm{c}}$ & $5.93 \pm 0.03^{\mathrm{c}}$ & $6.50 \pm 0.00^{\mathrm{b}}$ & $7.00 \pm 0.00^{\mathrm{a}}$ \\
\hline Specific gravity & $1.11 \pm 0.00$ & $1.11 \pm 0.00$ & $1.11 \pm 0.00$ & $1.11 \pm 0.01$ \\
\hline Titrable acidity (\% lactic acid) & $0.23 \pm 0.01^{\mathrm{a}}$ & $0.20 \pm 0.01^{\mathrm{b}}$ & $0.19 \pm 0.61^{\mathrm{c}}$ & $0.18 \pm 0.00^{\mathrm{d}}$ \\
\hline Ether extact (\%) & $6.07 \pm 0.12^{\mathrm{a}}$ & $5.37 \pm 0.12^{\mathrm{b}}$ & $5.23 \pm 0.09^{\mathrm{b}}$ & $4.83 \pm 0.12^{\mathrm{c}}$ \\
\hline Viscosity (centistrokes) & $243.50 \pm 0.09^{\mathrm{a}}$ & $190.47 \pm 0.15^{\mathrm{b}}$ & $184.47 \pm 0.15^{\mathrm{c}}$ & $175.23 \pm 0.23^{\mathrm{d}}$ \\
\hline
\end{tabular}

Table 2: Micro-biological qualities of Jersey cows raw milk samples at different stages of lactation

\begin{tabular}{|c|c|c|c|c|}
\hline Parameters & Colostrum & Early lactation Milk & Mid lactation Milk & Late lactation Milk \\
\hline $\begin{array}{c}\text { Total viable bacterial } \\
\text { count }(\mathrm{CFU} / \mathrm{ml})\end{array}$ & $2.3 \times 10^{2}$ & $5.0 \times 10^{2}$ & $8.6 \times 10^{2}$ & $1.9 \times 10^{3}$ \\
\hline Organism identified & Bacillus species & $\begin{array}{c}\text { Bacillus species } \text { and } \\
\text { Pseudomonas species }\end{array}$ & Bacillus species & $\begin{array}{c}\text { Bacillus species } \text { and } \\
\text { Pseudomonas species }\end{array}$ \\
\hline Total coliform count (CFU/ml) & - & - & - & $2.3 \times 10^{2}$ \\
\hline Organism identified & - & - & - & Aeromonas Species \\
\hline Total fungal count $(\mathrm{CFU} / \mathrm{ml})$ & $1.3 \times 10^{2}$ & $2.5 \times 10^{3}$ & $3.3 \times 10^{3}$ & $3.2 \times 10^{3}$ \\
\hline Organism identified & Rhizopus species & Rhizopus species & Aspergiillus species & $\begin{array}{c}\text { Rhizopus species } \\
\text { and Aspergiillus species }\end{array}$ \\
\hline
\end{tabular}

Coliform absent/ not detected

Table 3: International standards index (ISI) specifications for microorganism counts in raw milk Source: [2]

\begin{tabular}{|c|c|}
\hline Standard plate count $(\mathrm{cfu} / \mathrm{ml})$ & Grades \\
\hline Below $2.0 \times 10^{5}$ & Very good \\
\hline Between $2.0 \times 10^{5}$ and $1.0 \times 10^{6}$ & Good \\
\hline Between $1.0 \times 10^{6}$ and $5.0 \times 10^{6}$ & Fair \\
\hline Over $5.0 \times 10^{6}$ & Poor \\
\hline
\end{tabular}

\section{Discussion}

\section{Physicochemical properties of Jersey cows raw milk samples at different stages of lactation \\ The values of the physicochemical properties of Jersey cows raw milk samples at the different stages of lactation observed in this study were all significant $(\mathrm{P}<0.05)$ except for the values of specific gravity of Jersey cows milk that were similar $(\mathrm{P}>0.05)$.}

\section{pH}

The $\mathrm{pH}$ values ranged between 5.93 (early lactation milk) and 7.00 (late lactation milk). The observed $\mathrm{pH}$ range recorded in this study was comparable to the range of 6.59 to 6.93 for different types of milk samples that were analysed in Pakistan [3]. In another research, the $\mathrm{pH}$ value of 6.59 was reported for Jersey cattle milk [1], which was also within the range observed in the current research work.

\section{Specific gravity}

Specific gravity of the raw milk samples were the same $(P>0.05)$ in all the four stages of lactation and the value was 1.11. This recorded value of 1.11 was higher than the range of 1.02 to 1.07 reported by other researchers [3], and higher than the range of 1.025 to 1.03 , also earlier observed [4] for milk sold in milk markets in Uttar Pradesh, India. The fact that the specific gravity value of the milk samples were the same (1.11) at all the 4 stages of lactation could have reflected the fact that the water content in the milk samples at all the four stages of lactation were similar. Specific gravity was stated to be mainly the reflection of the water content that was present in a sample [3].

\section{Titrable acidity}

Titrable acidity values of the raw milk samples in the current research was least in the late lactation milk $(0.18 \%$ lactic acid) and highest in the colostrum ( $0.23 \%$ lactic acid). The range of 0.18 to $0.23 \%$ lactic acid recorded in this study was lower than the range of 0.81 to $1.44 \%$ lactic acid observed for various milk samples available in Pakistan [3] and also lower than $2.55 \%$ lactic acid for Jersey cattle raw milk reported in another research work [1]. The range 0.18 to $0.23 \%$ lactic acid observed in this study was higher than 0.116 to $0.128 \%$ lactic acid determined in market sold milk [4]. Some researchers who did a comparative study on the physiochemical properties of various milk samples reported the lactic acid content in cow milk to be $0.18 \%$ [8]. This value was within the range observed in the current study. It was explained that the titrable acidity value of milk could used to ascertain whether the milk was fit for processing into another milk product [2]. Natural or apparent acidity does not make the milk sour, but developed acidity due to excess lactic acid, adversely affects the quality of milk and alters its behaviour upon treatment [2].

\section{Fat}

Fat was stated to be the most vital constituent of milk in terms of economic value [4]. In this research, fat content of 


\section{International Journal of Science and Research (IJSR) \\ ISSN (Online): 2319-7064}

Index Copernicus Value (2013): 6.14 | Impact Factor (2015): 6.391

Jersey cattle raw milk sample was lowest in the late lactation milk $(4.83 \%)$, and highest in the colostrum $(6.07 \%)$. This observed range of 4.83 to $6.07 \%$ fat content was lower than $7.2 \%$ fat content of Jersey cattle milk observed by other workers [5], but slightly higher than the range of between 3.6 and $5.0 \%$ fat recorded in market sold milk [4] and in agreement with the value of $5.77 \%$ fat reported in other another research work [1] for the raw milk of Jersey cattle.

\section{Viscosity}

The observed value of the viscosity of the Jersey cattle raw milk samples ranged between 184.47 centistrokes (late lactation milk) and 243.50 centistrokes (colostrum). In a previous work [3], the viscosity range of 1.38 to 1.82 centipoise was observed for various milk samples in Pakistan.

\section{Micro-biological qualities of Jersey cows raw milk samples at different stages of lactation}

Total viable bacteria counts and organisms identified in the raw milk samples

Total viable bacteria counts ranged from $1.9 \times 10^{3} \mathrm{cfu} / \mathrm{ml}$ in the late lactation milk, $2.3 \times 10^{2} \mathrm{cfu} / \mathrm{ml}$ in the colostrum, 5.0 x $10^{2} \mathrm{cfu} / \mathrm{ml}$ in the early lactation milk and $8.6 \times 10^{2} \mathrm{cfu} / \mathrm{ml}$ in the mid lactation milk. The total viable bacteria counts observed in this study were below the $2.0 \times 10^{5} \mathrm{cfu} / \mathrm{ml}$ bacterial count of the ISI (International Standards Index) limits [2] for raw milk as outlined in Table 3. The Bacillus species and Pseudomonas species bacteria were identified. Thus, values obtained in the current study imply that the raw milk samples of the Jersey cows were of good quality and of very good grade. In an earlier study [9], the total viable bacteria count of $3.3 \times 10^{10} \mathrm{cfu} / \mathrm{ml}$ in fermented milk sold in the market was recorded and the bacteria identified included Bacillus mycoides and Staphylococcus aureus. It has been reported that milk produced under hygienic conditions from healthy cows should not contain more than $5.0 \times 10^{4} \mathrm{cfu} / \mathrm{ml}$ counts of bacteria [10].

Total coliform counts and organisms identified in the raw milk

There was no coliform organism observed in the colostrum, early lactation and mid lactation milk. Aeromonas species organism with a total coliform count of $2.3 \times 10^{2} \mathrm{cfu} / \mathrm{ml}$ was observed in the late lactation milk. The observed value of total coliform counts in the current study was within the safety limit of below $2.0 \times 10^{5} \mathrm{cfu} / \mathrm{ml}$ required (see Table 3 ). In earlier work, higher coliform counts of $3.46 \times 10^{11} \mathrm{cfu} / \mathrm{ml}$ was observed in the raw milk from hand milked White Fulani cows in Nigeria [11].

Total fungal counts and organisms identified in the raw milk samples

In this study, Rhizopus species and Aspergillus species fungi with total fungal counts of between $1.3 \times 10^{2} \mathrm{cfu} / \mathrm{ml}$ (colostrum), $2.5 \times 10^{3} \mathrm{cfu} / \mathrm{ml}$ (early lactation), $3.2 \times 10^{3}$ $\mathrm{cfu} / \mathrm{ml}$ (late lactation) and $3.3 \times 10^{3} \mathrm{cfu} / \mathrm{ml}$ (mid lactation) milk were observed. The presence of the fungal microorganisms as contaminants in the colostrum, early, mid and late lactation milk could be used as indices of poor sanitary conditions. However, the values of the fungal counts were below the $2.0 \times 10^{5} \mathrm{cfu} / \mathrm{ml}$ maximum microorganism counts for International Standard Index (ISI) specification given in Table 3. Also, in other earlier work, some research workers [11] observed higher yeast and mould fungi counts of $5.31 \mathrm{x}$ $10^{11} \mathrm{cfu} / \mathrm{ml}$ in the raw milk from hand milked White Fulani cows. The presence of the various micro-organisms observed in the Jersey cattle raw milk samples in this study was an indication of the need for the pasteurisation of raw milk in order to ensure its safety for human consumption. It can be concluded that the raw Jersey cattle milk samples (collected from the commercial dairy farm in Edu Local Government Area, Kwara state, Nigeria) at the different stages of lactation were of good physicochemical and microbiological qualities and this may be due to maintaining better hygiene conditions. However, there is need for pasteurization of the raw milk to ensure its safety for human consumption.

\section{References}

[1] T.R. Fayeye, A.H.A. Badmos, H.O. Okin, "Milk Yield and Quality of Holstein and Jersey Breeds of Cattle in Kwara State, Nigeria," Journal of Agricultural Research and Development, 12 (1), pp. $11-18,2013$.

[2] C.I. Kutty, S. Khamer, Milk and Milk Products Processing, $1^{\text {st }}$ Edition, Daya Publishing House, New Delhi, India, pp. 1 - 188, 2004.

[3] M. Imram, H. Khan, S.S. Hassan, R. Khan, "Physicochemical Characteristics of Various Milk Samples Available in Pakistan," Journal of Zhejiang University Science B, 9 (7), pp. 546-551, 2008.

[4] A. Payasi, A. Poonia, "Physicochemical and Microbiological Quality of Milk Sold in Milk Markets (Doodh Mandi) of Varanasi District, Uttar Pradesh, Indian Journal of Dairy Science, 68 (5), pp. 458-462, 2015.

[5] M. Czerniewics, K. Kielczewska, A. Kruk, "Comparison of some Physicochemical Properties of Milk from Holstein-Friesian and Jersey Cows," Polish Journal of Food and Nutrition Sciences, Volume 15/56, SI (1) pp. 61-64, 2006.

[6] A.O.A.C., Official Methods of Analysis. Association of Official Analytical Chemists, Washington DC, USA, pp. 48, 2005.

[7] (SAS) Statistical Analysis Systems, Institute Inc. SAS/ STAT. User's Guide Version 6, $3^{\text {rd }}$ Edition Cary. North Carolina, USA, 2000.

[8] Neeru Gakkhar, Anita Bhatia and N. Bhojak, "Comparative Study on Physiochemical Properties of Various Milk Samples." International Journal of Recent Scientific Research, Volume 6 (6), pp. 4436 - 4439, 2015.

[9] V.O. Adetunji, J.O. Ikheloa, A.M. Adedeji, D.O. Alonge, "An Evaluation of the Bacteria in Milk Products Sold in South-Western Nigeria," Nigerian Veterinary Journal, 24 (3), pp. 92-96, 2003.

[10]C.B. O'Connor, Traditional Cheese Making Manual. International Livestock Centre for Africa (ILCA), Addis Ababa, Ethiopia, pp. 43, 1993.

[11]O.O. Adewumi, O.M. Idowu, "Physicochemical, Microbial Load and Sensory Properties of Milk, Yoghurt with or without Garlic," Nigerian Journal of Animal Science, 16 (1) pp. $166-172,2014$.

\section{Volume 5 Issue 6, June 2016 www.ijsr.net}

